\title{
Eag1 potassium channels as markers of cervical dysplasia
}

\author{
CINDY SHARON ORTIZ ${ }^{1,3}$, DANIEL MONTANTE-MONTES ${ }^{3}$, MILENA SAQUI-SALCES ${ }^{3}$, \\ LUZ MARÍA HINOJOSA ${ }^{4}$, ARMANDO GAMBOA-DOMINGUEZ ${ }^{3}$, ELISABETH HERNÁNDEZ-GALLEGOS ${ }^{1}$, \\ BRAULIO MARTÍNEZ-BENIITEZ ${ }^{3}$, MARÍA DEL ROSARIO SOLÍS-PANCOATL ${ }^{1}$, ENRIQUE GARCIA-VILLA ${ }^{2}$, \\ ANA RAMÍREZ ${ }^{1}$, RICARDO AGUILAR-GUADARRAMA ${ }^{3}$, PATRICIO GARIGLIO², \\ LUIS A. PARDO ${ }^{5}$, WALTER STÜHMER ${ }^{5}$ and JAVIER CAMACHO ${ }^{1}$
}

\begin{abstract}
Departments of ${ }^{1}$ Pharmacology and ${ }^{2}$ Genetics and Molecular Biology, Centro de Investigación y Estudios Avanzados del IPN, Avenida Instituto Politécnico Nacional 2508, Mexico City 07360; ${ }^{3}$ Departamento de Patología, Instituto Nacional

de Ciencias Médicas y Nutrición ‘Salvador Zubirán’, Vasco de Quiroga 15 Tlalpan, Mexico City 14000;

${ }^{4}$ Departamento de Ginecología, Hospital General ‘Dr. Manuel Gea González', Calzada de Tlalpan 4800, Mexico City 14080, Mexico; ${ }^{5}$ Max-Planck-Institut für Experimentelle Medizin, Abteilung Molekulare Biologie Neuronaler Signale, Hermann Rein Strasse 3, 37075 Göttingen, Germany
\end{abstract}

Received April 13, 2011; Accepted May 26, 2011

DOI: $10.3892 / o r .2011 .1441$

\begin{abstract}
Human ether à-go-go 1 (Eag1) potassium channels are potential tumor markers and therapeutic targets for several types of malignancies, including cervical cancer. Estrogens and human papilloma virus oncogenes regulate Eag1 gene expression, suggesting that Eag1 may already be present in pre-malignant lesions. Therefore, Eag1 could be used as an early marker and/or a potential risk indicator for cervical cancer. Consequently, we studied Eag1 protein expression by immunochemistry in cervical cancer cell lines, normal keratinocytes, cervical cytologies from intraepithelial lesions, biopsies from cervical intraepithelial neoplasias (CIN 1, 2 and 3) and in normal smears from patients taking or not taking estrogens. Two hundred and eighty-six samples obtained by liquid-based cytology and fifteen CIN biopsies were studied. We observed Eag1 protein expression in the cervical cancer cell lines, as opposed to normal keratinocytes. Eag1 was found in $67 \%$ of the cervical cytologies from low-grade intraepithelial lesions and in $92 \%$ of the samples from high-grade intraepithelial lesions, but only in $27 \%$ of the normal samples. Noteworthy, morphologically normal cells obtained from dysplastic samples also exhibited Eag1 expression. In CIN biopsies we found that the higher the grade of the lesion, the broader the Eag1 protein distribution. Almost $50 \%$ of the normal patients
\end{abstract}

Correspondence to: Dr Javier Camacho, Department of Pharmacology, Centro de Investigación y Estudios Avanzados del IPN, Avenida Instituto Politécnico Nacional 2508, Mexico City 07360, Mexico

E-mail: fcamacho@cinvestav.mx

Key words: human ether à-go-go 1, cervical cancer, tumor markers, estrogens, potassium channels taking estrogens displayed Eag1 expression. We suggest Eag1 as a potential marker of cervical dysplasia and a risk indicator for developing cervical lesions in patients taking estrogens. Eag1 detection in cervical cancer screening programs should help to improve early diagnosis and decrease mortality rates from this disease.

\section{Introduction}

Cervical carcinoma is one of the main causes of cancer-related mortality among women, particularly in developing countries $(1,2)$. Thus, detection of pre-cancerous lesions is a major issue to be addressed by health care programs. Epidemiological studies have identified high-risk human papilloma viruses (HR-HPVs) as a major risk factor for developing cervical cancer (3). Prophylactic vaccines against HPVs have been shown to significantly protect against HPV infection, decreasing the incidence of cervical cancer lesions $(4,5)$. In addition, extended use of oral contraceptives containing estrogens correlates with an increase in the incidence of cervical cancers $(6,7)$. Estrogens play a proliferative role in various types of cancer cells, and expression of either estrogen receptors (ERs) or aromatase has been demonstrated to stimulate the proliferation of tumor cells derived from mammary gland, lung and cervical cancers (8-10).

Cervical carcinoma is preceded by the appearance of lowand high-grade intraepithelial lesions (LSILs and HSILs, respectively) (11). Despite the successful introduction of the Pap smear test and the existence of several tests detecting early cancerous lesions, cervical cancer is still a major public health problem. Thus, novel pre-cancer markers may serve as indicators for acute risk of developing cervical cancer.

Ether à-go-go 1 (Eag1) potassium channels possess oncogenic properties (12). Human Eag1 mRNA shows restricted distribution in healthy tissues, being expressed mainly in the brain, slightly in the placenta, testis, adrenal gland and transiently in myoblasts (12-14). A physiological role for Eag1 
providing the hyperpolarization needed prior to cell fusion, has been proposed for myoblast fusion (13). Conversely, Eag1 is more abundantly expressed in cancer cells from different histogenesis including cervical, lung, breast, colon and prostate cancer (14-16). Because of this particular distribution, Eag1 is considered as a powerful tumor marker for many types of cancers. Moreover, other findings indicate a correlation between Eag1 expression levels and reduced overall survival in patients with colon carcinoma, soft-tissue sarcoma and acute myeloid leukemia (16-18). Inhibition of Eag1 expression by either antisense oligonucleotides or RNA silencing was found to significantly decrease proliferation of several tumor cell types $(12,17)$. In addition, inhibition of Eag1 channel activity by the non-specific Eag1 inhibitors, imipramine or astemizole, has been suggested to decrease the proliferation of cancer cells $(17,19,20)$. Astemizole was also found to inhibit tumor growth in vivo in an Eag1-dependent manner (21). In addition, specific blockage of Eag1 with monoclonal antibodies inhibited tumor cell growth both in vitro and in vivo (22). Accordingly, Eag1 is also considered a promising therapeutic target for cancer.

We previously reported that normal cervical tissue samples from women with negative Pap smears displayed Eag1 mRNA expression (15). One of these patients presented with HR-HPV infection, another had a paratubaric cystadenoma, and a third patient presented with endometrial hyperplasia. These findings led us to hypothesize that Eag1 is an early indicator of cellular proliferation. In accordance, Eag1 mRNA has been detected in the 'tumor-free' mammary gland surrounding breast carcinoma tissue (14) and in human diverticulitis which has the potential to transform into colonic cancer (16). All of these observations suggest Eag1 expression as a potential early sign of cellular hyperproliferation.

Estrogens and HPV oncogenes (E6/E7) up-regulate Eag1 expression in normal and/or cancer cells (23). Imipramine, astemizole and monoclonal antibodies inhibiting Eag1 channel activity were found to decrease the cell proliferation of keratinocytes transfected with E6/E7 oncogenes (23). This Eag1 regulation by etiological factors of cervical cancer strongly suggests that Eag1 may be detected in cervical precancerous lesions and, therefore, may function as an early marker and/or a risk indicator for cervical cancer.

Here, we demonstrated that Eag1 protein was differentially overexpressed in at-risk cervical cytologies compared to normal cervix. Furthermore, the levels of Eag1 expression increased from low- to high-grade intraepithelial lesions. Moreover, Eag1 was found in a high percentage of normal patients using estrogens. Our results strongly suggest Eag1 as a potential marker of pre-cancerous intraepithelial lesions and as a likely risk indicator for cervical cancer. Detection of Eag1 by cervical cancer screening programs should help to improve the detection of intraepithelial lesions and decrease mortality from cervical cancer.

\section{Materials and methods}

Biological samples. Liquid-based cervical cytologic samples were studied in a retrospective manner from patients who attended either the Cytology Department or the Dysplasia Clinic at the General Hospital 'Dr Manuel Gea González' in
Mexico City, following local ethical considerations (Protocol no. 11-04-2010 approved by the ethics committee of the same hospital). Cervical cytologies were obtained with a cytobrush placed in a 20-ml container with fixing solution (Bio SB, Santa Barbara, CA) and transported at room temperature to the Department of Pathology of the National Institute of Medical Science and Nutrition 'Salvador Zubirán' (INCMNSZ) for further processing and storage. The samples were vortexed for $45 \mathrm{sec}$, and $10 \mathrm{ml}$ of each cytology specimen was placed in a tube containing $3 \mathrm{ml}$ of liquid density gradient solution (Bio $\mathrm{SB})$. Then, the samples were centrifuged for $15 \mathrm{~min}(1000 \mathrm{x} \mathrm{g})$ at $25^{\circ} \mathrm{C}$, the supernatant was eliminated, and the cell pellet was homogenized in $1 \mathrm{ml}$ of distilled water for each millimeter of cell pellet. The sample $(1 \mathrm{ml})$ was placed for $15 \mathrm{~min}$ on a charged glass slide (Biocare Medical, Concord, CA). The cells were then washed with $96 \%$ ethanol and dried at room temperature. Subsequently, a standard staining protocol was carried out.

The samples were independently staged by histological analysis of the cervical biopsies classified according to the Bethesda System for reporting cervical cytology (11) as normal, low-grade squamous intraepithelial lesions (LSILs) or high-grade squamous intraepithelial lesion (HSILs). None of the patients had received any treatment for cervical dysplasia.

Human cervical cancer cells were also obtained from previously established primary cultures, formerly characterized to express Eag1, cytokeratins and the E7 gene from HPV-16 (15), supporting their cancer epithelial nature. Cervical cancer cell lines HeLa and $\mathrm{SiHa}$ were obtained from the American Type Culture Collection (Manassas, VA) and cultured according to the supplier's instructions. Normal human epidermal keratinocytes (from neonatal foreskins) were obtained from Millipore Corporation (Billerica, MA, USA) and cultured according to the supplier's instructions. Normal human hippocampus and cervical tissue were obtained from the Instituto Nacional de Nutrición y Ciencias Médicas 'Salvador Zubirán' tissue collection, in Mexico City. Cervical intraepithelial neoplasia (CIN) biopsies for comparison with cervical smears (CIN 1-3, five biopsies of each grade) were retrieved from the consultation files of one of the authors (A.G.D.).

Immunocytochemistry and immunohistochemistry. Eag1 immunochemistry was performed as previously described $(14,23)$. The monoclonal anti-Eag1 antibody has been validated and demonstrated to be very specific, as it does not bind to hErg (human Eag-related gene) channels and discriminates between Eag1 and Eag2. The latter is the protein more closely related to Eag1 (22). Using this antibody, the presence of Eag1 in human cervical biopsies, in cervical cancer cells from primary cultures and in CHO (Chinese hamster ovary) cells transfected with Eag1, in contrast to non-transfected $\mathrm{CHO}$ cells has been demonstrated (15). Tissue serial sections $(1.5 \mu \mathrm{m})$ were mounted on charged glass slides and deparaffinized for 4-5 $\mathrm{min}$ in xylene, xylene/absolute alcohol (1:1), absolute alcohol (JT Baker), ethanol (Sigma) and washed with buffered solution (PBS/Tween-20) (Ventana Medical, Tucson, AZ). Cervical smear samples obtained by liquid-based cytology were rehydrated with absolute alcohol, ethanol and PBS, in a similar manner as the biopsies. For antigen retrieval, slides were 

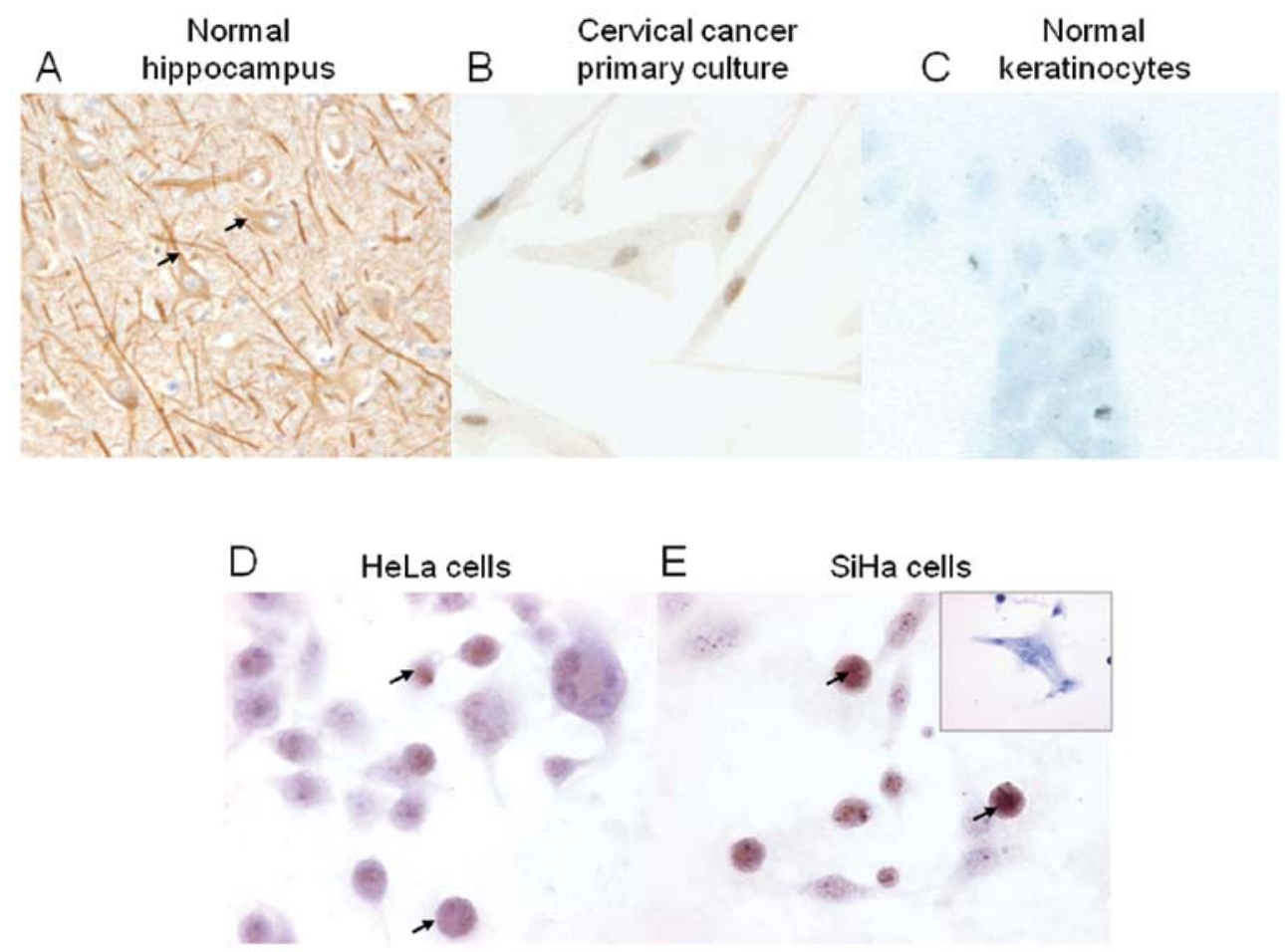

Figure 1. Human Eag1 protein expression in normal and cancer samples. Brown immunostaining reveals Eag1 expression. (A) Normal hippocampus, (B) cervical cancer cells from a primary culture and (C) normal keratinocytes which do not express Eag1 mRNA (23) displayed no Eag1 protein expression. (D) HeLa cells (E) SiHa cells; the inset shows no Eag1 staining when the corresponding epitope was incubated in the presence of the Eag1 antibody.

immersed in 0.1 M EDTA ( $\mathrm{pH} 9.2$ ), boiled for 30 min and allowed to cool at room temperature. Slides were blocked for 10 min with dual endogenous enzyme blocker (Dako, cat. no. S2003), followed by a further block of $10 \mathrm{~min}$ with Background Sniper (Biocare Medical, cat. no. BS966L) and incubated for $1 \mathrm{~h}$ with the anti-Eag1 antibody (1:100) at room temperature. Then, slides were treated for $10 \mathrm{~min}$ with $100 \mu \mathrm{l}$ of MACH $4^{\mathrm{TM}}$ mouse probe (Biocare Medical, cat. no. M4U534 L), followed by a 10-min incubation with MACH 4 horseradish peroxidase polymer (Biocare Medical, cat. no. M4U534 L). The specific staining reaction was completed by incubating the slides in the presence of 3,3'-diaminobenzidine in buffer reaction solution (Dako) and by washing with distillated water. Slides were counterstained with hematoxylin (Dako), and rinsed with water and a sequence of ethanol, absolute ethanol, xylene/absolute ethanol and xylene. Slides were mounted with resin (Merck, Darmstadt) and observed with either a Nikon Eclipse E50i microscope (New York, NY, USA) or an Olympus Optical model CHS microscope (Japan) using an Olympus x40 (0.65) and x100 (0.65) objectives. Incubation of all of the samples in the absence of the primary antibody gave no signal (data not shown). Brown-colored immunostaining revealed Eag1 expression. Positive staining was considered when at least $5 \%$ of the cells displayed Eag1 expression. A fusion protein containing the epitope of the antibody, which is located close to the putative pore region of Eag1, was used as a control for antibody specificity (22).

Data analysis. The $\chi^{2}$ independence test (24) was used to analyze the association between Eag1 expression and the pres- ence of cervical dysplasia or estrogen use. Odds ratio (OR), p-value for OR, and confidence intervals at $95 \%$ (95\% IC) were calculated with either Stata or SPSS statistical programs, considering $\mathrm{p}$-values $<0.05$ as significant.

\section{Results}

Eag1 protein in human sample preparations. Antibodies used for diagnostic purposes must detect the corresponding protein only in the affected tissues and should not give a signal in cells not expressing the protein of interest. According to previous reports of Eag1 expression $(15,25)$, Eag1 protein was detected in human hippocampus and cells from a cervical cancer primary culture (Fig. 1A and B, respectively). Normal keratinocytes are an appropriate cell type to serve as a negative control. Since Eag1 mRNA is absent in normal keratinocytes (23), we looked for Eag1 protein in these cells. Normal keratinocytes incubated with the Eag1 antibody gave no signal (Fig. 1C). Thus, this cell-type is a suitable negative control for Eag1 protein expression. Eag1 mRNA expression has been reported in cervical cancer cell lines HeLa and $\mathrm{SiHa}(12,23)$. Here, we showed that Eag1 was expressed in these cells at the protein level (Fig. 1D and E, respectively). Upon incubation of SiHa cells with the Eag1 antibody pre-adsorbed with a fusion protein containing its epitope, an area close to the putative pore region gave no staining signal (inset, Fig. 1E). Taken together, these observations confirm the specificity of the Eag1 antibody used. In addition, we also propose the use of cervical cancer cell lines and normal keratinocytes as either positive or negative controls of Eag1 protein expression, respectively. 


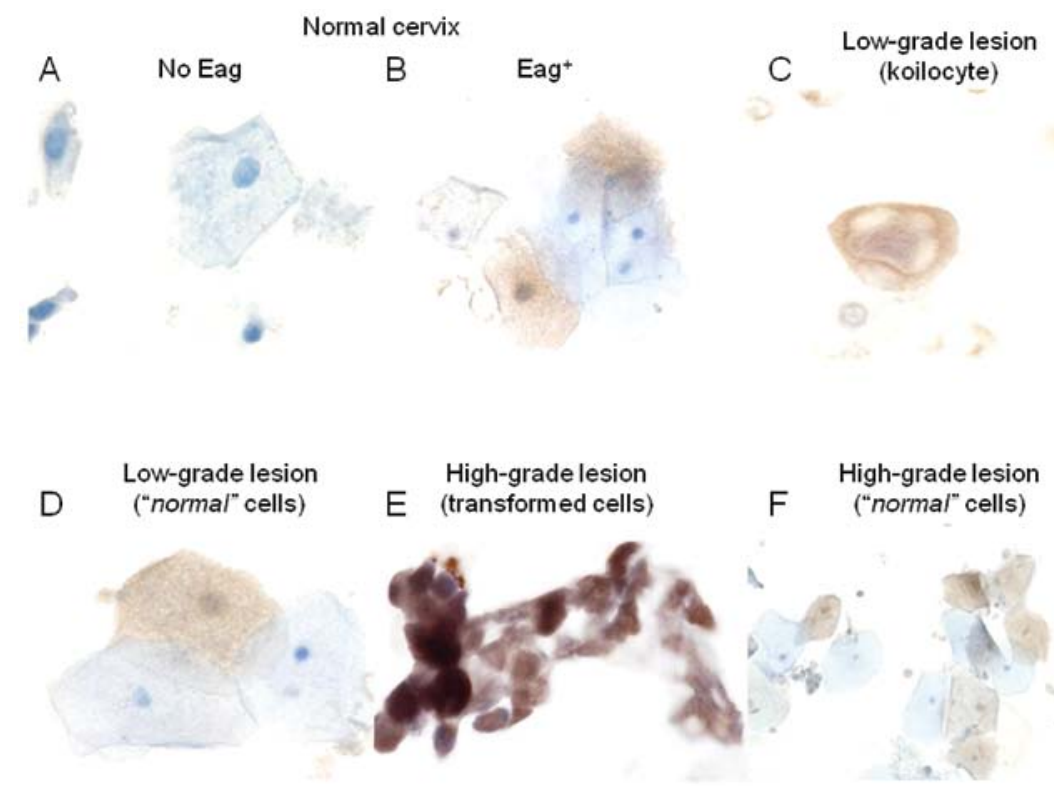

Figure 2. Eag1 in cervical cytologies. Brown immunostaining reveals Eag1 expression. (A) Cells from normal cervix without Eag1 expression, (B) cells from normal cervix showing Eag1 expression, (C) koilocytes from LSIL showing morphological changes and Eag1 expression, (D) morphologically normal cells from LSIL expressing Eag1, (E) HSIL cells with evident morphologic changes, and (F) morphologically normal cells from HSIL.

A

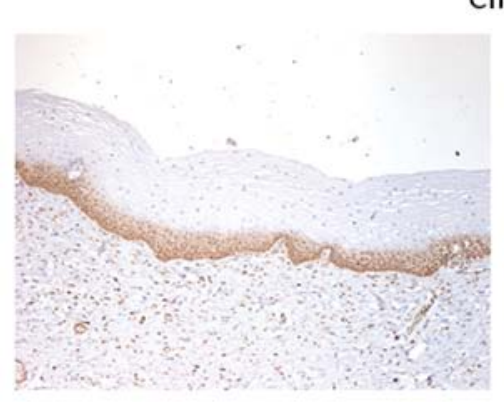

B

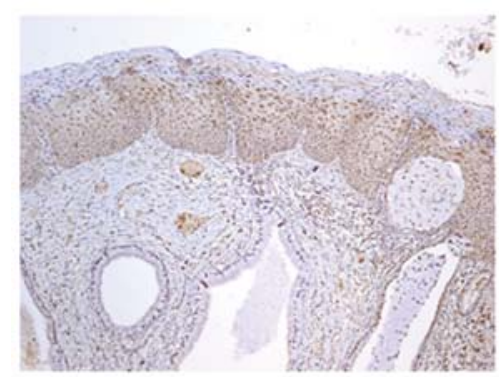

CIN 1

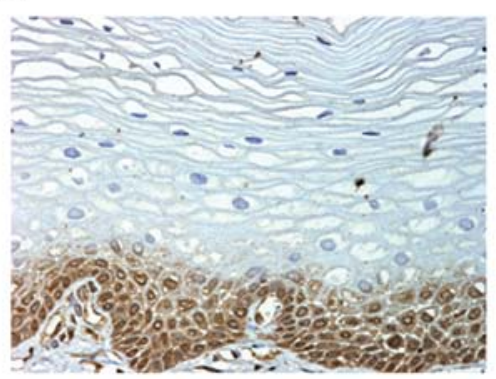

CIN 2

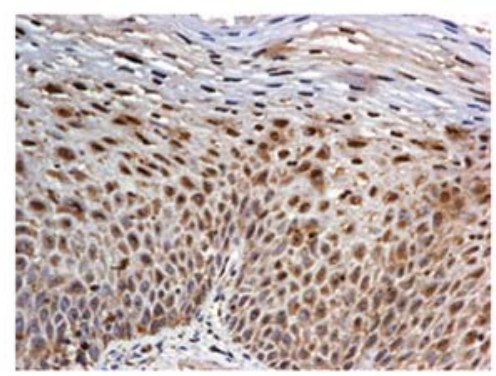

C

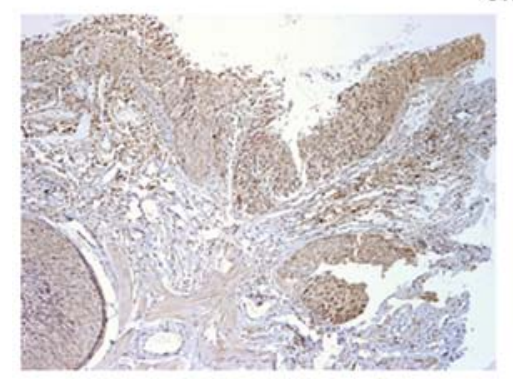

CIN 3

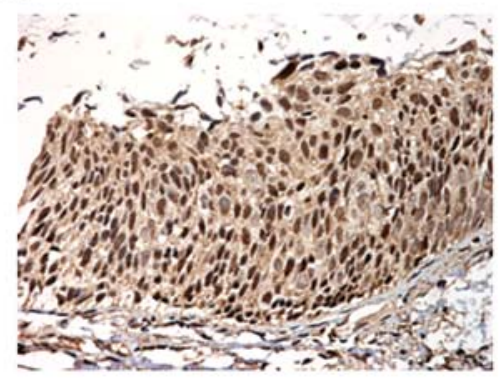

Figure 3. Eag1 in cervical biopsies of intraepithelial neoplasias. Brown immunostaining reveals Eag1 expression. (A) CIN 1, (B) CIN 2, (C) CIN 3. Immunochemistry in the absence of the Eag1 antibody gave no signal (data not shown). (Left panels x10, right panels x40). 
Table I. Eag1 protein expression in normal and dysplastic cervical cytologies.

\begin{tabular}{lllll}
\hline & & \multicolumn{3}{c}{ Intraepithelial lesions } \\
\cline { 3 - 5 } & Normal cervix & $\begin{array}{l}\text { Low } \\
\text { grade }\end{array}$ & $\begin{array}{l}\text { High } \\
\text { grade }\end{array}$ & Total \\
\hline $\begin{array}{l}\text { Eag1 } \\
{[\text { no./total }(\%)]}\end{array}$ & $51 / 184(27)$ & $24 / 36(67)$ & $12 / 13(92)$ & $36 / 49(73)$ \\
\hline
\end{tabular}

Table II. Eag1 expression in normal cervical cytologies from patients using estrogens.

\begin{tabular}{lccccccc}
\hline & \multicolumn{2}{c}{ Estrogen use } & & \multicolumn{3}{c}{ Statistical analysis } \\
\cline { 2 - 3 } \cline { 5 - 7 } & No & Yes & & OR & p-value & $95 \%$ CI \\
\hline $\begin{array}{l}\text { Eag1 }{ }^{+} \\
{[\text {no./total (\%)] }}\end{array}$ & $12 / 44(27)$ & $28 / 57(49)$ & 3.54 & 0.003 & $1.55-8.06$ \\
\hline
\end{tabular}

Therefore, these results allow the reliable identification of at-risk Eag1-expressing tissues, from cervical smears.

Eagl protein in normal and dysplastic cervical cytologies. Fig. 2 shows examples of Eag1 protein expression in smears from either normal cervix or intraepithelial lesions. Most of the normal samples (133 out of 184, 73\%) did not display Eag1 expression (Fig. 2A, Table I); however, Eag1 expression was noted in 51 out of the 184 normal samples (Fig. 2B, Table I). Both low- and high-grade intraepithelial lesions (LSILs and HSILs, respectively) expressed Eag1. Fig. 2C shows Eag1 expression in an LSIL koilocyte. In this case the staining was mainly focal to cells with characteristics of HPV infection. Most of the cells in the cervical cytologies were keratinocytes from the exocervix. No considerable staining was observed in glandular cells. Notably, Eag1 was also observed in morphologically normal cells from an LSIL sample (Fig. 2D). This finding is important since in some cases only apparently normal cells are collected despite the presence of intraepithelial lesions and such samples might be staged as normal cervix.

Eag1 expression was found to be stronger in the HSILs when compared to that in the LSILs. Fig. 2E shows an HSIL cervical cytology with evident morphological alterations. The intense brown staining denotes a high expression level and extended Eag1 subcellular distribution in the HSILs, in contrast to lower expression and a more delimited distribution (nuclear or plasma membrane) in the LSILs. Eag1 was also found in morphologically normal cells from HSILs (Fig. 2F). These results strongly suggest Eag1 as a marker of dysplasia with the advantage of detecting Eag1 in morphologically normal cells obtained from intraepithelial lesions. A summary of Eag1 expression in normal and dysplastic samples is provided in Table I. Eag1 protein expression was found in $27 \%$ $(51 / 184)$ of the women with normal cervical cytology. The probability increased to $67 \%(24 / 36)$ in the LSILs, and increased to $92 \%(12 / 13)$ in the HSIL samples. The high percentage of dysplasias displaying Eag1 strongly suggests an association between Eag1 expression and the presence of intraepithelial lesions (Pearson's $\chi^{2}=34.62, \mathrm{p} \leq 0.001$ ). This association appears to be stronger for high-grade intraepithelial lesions $\left(\chi^{2}=23.29, \mathrm{p} \leq 0.001\right)$ than for low-grade lesions $\left(\chi^{2}=20.33, p \leq 0.001\right)$. Despite this, Eag1 expression was not sufficient to distinguish between LSILs and HSILs $\left(\chi^{2}=3.2\right.$, no statistical significance). These results strongly advocate the use of Eag1 as a marker of pre-cancerous cervical intraepithelial lesions. Our analysis of Eag1 as a marker of cervical dysplasia indicates sensitivity and specificity values of 73 and $71 \%$, respectively.

Eagl protein in the biopsies from cervical intraepithelial lesions (CIN 1-3). The clear difference in Eag1 immunostaining between LSILs and HSILs found in the cervical cytologies prompted us to investigate Eag1 protein expression in the biopsies from cervical intraepithelial neoplasia of different grade (CIN 1, 2 and 3). Fig. 3 shows a very clear differential Eag1 expression depending on the grade of the lesion in such biopsies. Higher grades of the lesion revealed a broader Eag1 distribution. CIN 1 biopsies showed Eag1 expression mainly in basal cells, while CIN 3 samples displayed Eag1 protein in most cells from the basal layer to the surface. CIN 2 samples showed an intermediate Eag1 expression between CIN 1 and CIN 3. We studied five samples of each CIN grade and found a very similar expression pattern for all of the samples of the corresponding grade. These observations validate our findings in cervical cytologies.

Eagl protein in normal cervix from patients using estrogens. Since estrogens induce Eag1 gene expression in vitro, we studied Eag1 expression in normal cervical smears from patients using estrogens as either hormonal replacement therapy or contraceptives. Eag1 expression in these cytologies was found in almost 50\% (28/57) of the samples (Table II). In most cases, Eag1 immunostaining was observed in the nucleus (data not shown). Statistical analysis revealed an association between estrogen use and Eag1 expression $\left(\chi^{2}=9.68\right)$. Calculated odds ratio strongly suggests estrogen use as a factor affecting Eag1 expression.

\section{Discussion}

Detection of pre-cancerous lesions is a major issue to be addressed worldwide in health care programs. Eag1 potassium channels have gained great interest as potential markers and therapeutic targets for cancer. Eag1 regulation by chemical carcinogens, HPV oncogenes, and estradiol $(16,23)$, additionally suggests that Eag1 channels may also serve as early indicators of malignant transformation.

Here, we showed that Eag1 channels are differentially expressed in cervical smears from normal and pre-cancerous cervical lesions, as well as in cervical biopsies from different CIN grades. Our findings strongly suggest an association between Eag1 expression and cervical dysplasia. Eag1 expression in approximately $10 \%$ of the morphologically normal cells coming from the intraepithelial lesions, could be a very important indicator for the presence of potential lesions in 
those cases where no abnormal cells are observed by cytology of cervical tissue. Based on these observations, an early cervical cancer detection kit based on the detection of Eag1 is proposed. In addition to a sample from the patient, such a detection kit should include positive and negative controls for Eag1 expression in cervical cancer cell lines and normal keratinocytes, respectively.

Considering both the percentages of normal cervical cytologies displaying Eag1 expression and the observation of Eag1 in all of the CIN biopsies, as well as the initial sensitivity and specificity values here obtained, a wide population study is needed in order to fully validate Eag1 as a marker of dysplasia. Such a study should also investigate the potential association between Eag1 expression and main cervical cancer etiological factors, such as HPV infection, expression of other alternative markers such as p16 and Ki67, and a complete histological analysis of both cervical cytologies and biopsies. This broad study would provide more robust data for the validation of Eag1 as a marker of cervical dysplasia.

We also observed a differential subcellular expression of Eag1. The presence of Eag1 in the nucleus was expected since a perinuclear localization of Eag1 channels was previously observed in various types of tumors and cells expressing HR-HPV oncoproteins $(14,17,23)$. A C-terminal fragment of a voltage-gated calcium channel was found to translocate to the nucleus and regulate transcription (26), and whether Eag1 plays a similar role in the nucleus remains to be elucidated.

Our results also suggest that Eag1 expression is a potential risk indicator of developing cervical lesions in patients using estrogens. A wide population study is also needed here in order to determine the association between Eag1 expression and the duration or type of estrogen used (injected, oral). In addition, a prospective study is also needed to ascertain what percentage of patients using estrogens and showing Eag1 expression develop cervical lesions. It may be equally important to study the association between Eag1 expression and other conditions where estrogenic imbalances are noted, for instance in obese women. Finally, this study provides a strong rationale for performing wide population and follow-up studies in order to endorse the final clinical use of Eag1 as a dysplasia marker.

Despite the successful introduction of the Pap smear test and the existence of tests detecting pre-cancerous lesions, cervical cancer is still a major public health issue in many countries. Thus, novel identifications of pre-cancer markers and indicators of cervical cancer risk are necessary. Our results propose Eag1 as a potential marker of cervical dysplasia and a likely risk indicator for developing cervical lesions in patients using estrogens. Detection of Eag1 in cervical cancer screening programs may improve the detection of intraepithelial lesions and decrease mortality from cervical cancer.

\section{Acknowledgements}

This study was supported, in part, by CONACyT, grant 45753 to J.C. The authors would like to thank Verónica Cadena for the secretarial assistance; Guadalupe Montiel and Gabriela Cedillo for the technical assistance, and Dr Nassira Martínez de Larios and Lucia Hernández-Flores for obtaining the cytological samples.

\section{References}

1. Franco EL, Duarte-Franco E and Ferenczy A: Cervical cancer: epidemiology, prevention and the role of human papilloma virus infection. CMAJ 164: 1017-1025, 2001.

2. World Health Organization (WHO). Cervical Cancer Incidence in Mexico (http://www.who.int/infobase/report.aspx?rid=119).

3. Walboomers JMM, Jacobs MV, Manos MM, Bosch FX Kummer JA, Shah KV, Snijders PJF, Peto J, Meijer CJLM and Munoz N: Human papillomavirus is a necessary cause of invasive cervical cancer worldwide. J Pathol 189: 12-19, 1999.

4. Koutsky LA, Ault KA, Wheeler CM, Brown DR, Barr E, Alvarez FB, Chiacchierini LM and Jansen KU: A controlled trial of a human papillomavirus type 16 vaccine. N Engl J Med 347: 1645-1651, 2002.

5. Villa LL, Costa RLR, Petta CA, Andrade RP, Ault KA, Giuliano AR, Wheeler CM, Koutsky LA, Malm C, Lehtinen M, Skjeldestad FE, Olsson SE, Steinwall M, Brown DR, Kurman R, Ronnett BM, Stoler MH, Ferenczy A, Harper DM, Tamms GM, Yu J, Lupinacci L, Railkar R, Taddeo FJ, Jansen KU, Esser MT, Sings HL, Saah AJ and Lupinacci L: Prophylactic quadrivalent human papillomavirus (types 6,11,16, and 18) L1 virus-like particle vaccine in young women: a randomised double-blind placebo-controlled multicentre phase II efficacy trial. Lancet Oncol 6: 271-278, 2005.

6. Moreno V, Bosch FX, Munoz N, Meijer CJLM, Shah DV, Walboomers JMM, Herrero R and Franceschi S: Effect of oral contraceptives on risk of cervical cancer in women with human papillomavirus infection: the IARC multicentric case-control study. Lancet 359: 1085-1092, 2002.

7. Munoz N, Franceschi S, Bosetti C, Moreno V, Herrero R, Smith JS, Shah KV, Meijer CJLM and Bosch FX: Role of parity and human papillomavirus in cervical cancer: the IARC multicentric case-control study. Lancet 359: 1093-1110, 2002.

8. Jordan VC: Selective estrogen receptor modulation: concept and consequences in cancer. Cancer Cell 5: 207-213, 2004.

9. Weinberg OK, Marquez-Garban DC, Fishbein M, Goodglick L, Garban HJ, Dubinett SM and Pietras RJ: Aromatase inhibitors in human lung cancer therapy. Cancer Res 65: 11287-11291, 2005.

10. Nair HB, Luthra R, Kirma N, Liu YG, Flowers L, Evans D and Tekmal RR: Induction of aromatase expression in cervical carcinomas: effects of endogenous estrogen on cervical cancer cell proliferation. Cancer Res 65: 11164-11173, 2005.

11. Solomon D and Nayar R: The Bethesda System for Reporting Cervical cytology. Springer-Verlag, New York, 2004.

12. Pardo LA, Del Camino D, Sánchez A, Alves F, Brüggemann A, Beckh S and Stühmer W: Oncogenic potential of EAG $\mathrm{K}^{+}$ channels. EMBO J 18: 5540-5547, 1999.

13. Occhiodoro TL, Bernheim L, Liu JH, Bijlenga P, Sinnreich M, Bader CR and Fischer-Lougheed J: Cloning of a human ether-ago-go potassium channel expressed in myoblasts at the onset of fusion. FEBS Lett 434: 177-182, 1998.

14. Hemmerlein B, Weseloh RM, DeQueiroz FM, Knötgen H, Sánchez A, Rubio ME, Martin S, Schliephacke T, Jenke M, Heinz-Joachim-Radzun, Stühmer W and Pardo LA: Overexpression of Eag1 potassium channels in clinical tumours. Mol Cancer 5: 41, 2006.

15. Farias LMB, Ocaña DB, Díaz L, Larrea F, Avila-Chávez E, Cadena A, Hinojosa LM, Lara G, Villanueva LA, Vargas C, Hernández-Gallegos E, Camacho-Arroyo I, Dueñas-González A, Pérez-Cárdenas E, Pardo LA, Morales A, Taja-Chayeb L, Escamilla J, Sánchez-Peña $\mathrm{C}$ and Camacho J: Ether à go-go potassium channels as human cervical cancer markers. Cancer Res 64: 6996-7001, 2004.

16. Ousingsawat J, Spitzner M, Puntheeranurak S, Terraciano L, Tornillo L, Bubendorf L, Kunzelmann K and Schreiber R: Expression of voltage-gated potassium channels in human and mouse colonic carcinoma. Clin Cancer Res 13: 824-831, 2007.

17. DeQueiroz FM, Suarez-Kurtz G, Stühmer W and Pardo LA: Ether à go-go potassium channel expression in soft tissue sarcoma patients. Mol Cancer 5: 42, 2006.

18. Agarwal JR, Griesinger F, Stuhmer W and Pardo LA: The potassium channel ether à go-go is a novel prognostic factor with functional relevance in acute myeloid leukemia. Mol Cancer 9: $18,2010$.

19. Spitzner M, Ousingsawat J, Scheidt K, Kunzelmann K and Schreiber R: Voltage-gated $\mathrm{K}^{+}$channels support proliferation of colonic carcinoma cells. FASEB J 21: 35-44, 2007. 
20. Gavrilova-Ruch O, Schönherr K, Gessner G, Schönherr R, Klapperstuck T, Wohlrab W and Heinemann SH: Effects of imipramine on ion channels and proliferation of IGR1 melanoma cells. J Membr Biol 188: 137-149, 2002.

21. Downie BR, Sánchez A, Knötgen H, Contreras-Jurado C Gymnopoulos M, Weber C, Stühmer W and Pardo LA: Eag1 expression interferes with hypoxia homeostasis and induces angiogenesis in tumors. J Biol Chem 238: 36234-36240, 2009.

22. Gómez-Varela D, Zwick-Wallasch E, Knötgen H, Sánchez A, Hettmann T, Ossipov D, Weseloh R, Contreras-Jurado C, Rothe M, Stühmer W and Pardo LA: Monoclonal antibody blockade of the human Eag1 potassium channel function exerts antitumor activity. Cancer Res 67: 7343-7349, 2007.

23. Díaz L, Ceja-Ochoa I, Restrepo-Angulo I, Larrea F, AvilaChávez E, García-Becerra R, Borja-Cacho E, Barrera D, Ahumada E, Gariglio P, Alvarez-Rios E, Ocadiz-Delgado R, Garcia-Villa E, Hernandez-Gallegos E, Camacho-Arroyo I, Morales A, Ordaz-Rosado D, Garcia-Latorre E, Escamilla J, Sanchez-Pena LC, Saqui-Salces M, Gamboa-Dominguez A, Vera E, Uribe-Ramirez M, Murbartian J, Ortiz CS, RiveraGuevara C, De Vizcaya-Ruiz A and Camacho J: Estrogens and human papilloma virus oncogenes regulate Eag1 potassium channel expression. Cancer Res 69: 3300-3307, 2009.
24. Chan YH: Biostatistics 103: qualitative data - tests of independence. Singapore Med J 44: 498-503, 2003.

25. Martin S, DeOliveira CL, DeQueiroz FM, Pardo LA, Stühmer W and Del Bel E: Eag1 potassium channel immunohistochemistry in the CNS of adult rat and selected regions of human brain. Neuroscience 155: 833-844, 2008.

26. Gomez-Ospina N, Tsuruta F, Barreto-Chang O, Hu L and Doltmesch R: The $\mathrm{C}$ terminus of the L-type voltage-gated calcium channel $\mathrm{Ca}_{v} 1.2$ encodes a transcription factor. Cell 127: 591-606, 2006 